This is an author produced version of a paper published in Biology and Fertility of Soils.

This paper has been peer-reviewed and is proof-corrected, but does not include the journal pagination.

Citation for the published paper:

Parvage, Mohammed Masud; Ulén, Barbro; Eriksson, Jan; Strock, Jeffery; and Kirchmann, Holger. (2013) Phosphorus Availability in Soils Amended with Wheat Residue Char. Biology and Fertility of Soils. Volume: 49, Number: 2, pp 245-250.

http://dx.doi.org/10.1007/s00374-012-0746-6.

Access to the published version may require journal subscription.

Published with permission from: Springer Verlag.

Standard set statement from the publisher:

An author may self-archive an author-created version of his/her articleon his/her own website and or in his/her institutional repository. He/she may also deposit this version on his/her funder's or funder's designatedrepository at the funder's request or as a result of a legal obligation,provided it is not made publicly available until 12 months afterofficial publication. He/ she may not use the publisher's PDF version, which is posted on www.springerlink.com, for the purpose of selfarchivingor deposit. Furthermore, the author may only post his/herversion provided acknowledgement is given to the original source ofpublication and a link is inserted to the published article on Springer'swebsite. The link must be accompanied by the following text:"The final publication is available at www.springerlink.com”.

Epsilon Open Archive http://epsilon.slu.se 
Biology and Fertility of Soils

February 2013, Volume 49, Issue 2, pp 245-250

DOI: 10.1007/s00374-012-0746-6; Print ISSN: 0178-2762; Online ISSN: 1432-0789

\title{
Phosphorus Availability in Soils Amended with Wheat Residue Char
}

\author{
Mohammed Masud Parvage ${ }^{\mathrm{a} *}$, Barbro Ulén ${ }^{\mathrm{a}}$, Jan Eriksson ${ }^{\mathrm{a}}$, Jeffery Strock ${ }^{\mathrm{ab}}$, and Holger \\ Kirchmann $^{\mathrm{a}}$ \\ ${ }^{a}$ Department of Soil and Environment, \\ ${ }^{\mathrm{b}}$ Southwest Research and Outreach Center, \\ Swedish University of Agricultural Sciences, University of Minnesota, PO Box 428, 23669 \\ Box 7014, SE-750 07 Uppsala, Sweden; \\ 130th Street Lamberton, MN 56125, USA. \\ *Correspondence: masud.parvage@slu.se; \\ Tel +46 (0) 18671223; Fax +46 (0) 672795
}

\begin{abstract}
Plant availability and risk for leaching and/or runoff losses of phosphorus (P) from soils depends among others on $\mathrm{P}$ concentration in the soil solution. Water soluble $\mathrm{P}$ in soil measures soil solution $\mathrm{P}$ concentration. The aim of this study was to understand the effect of wheat residue char (biochar) addition on water soluble $\mathrm{P}$ concentration in a wide range of biochar amended soils. Eleven agricultural fields representing dominant soil texture classes of Swedish agricultural lands were chosen. Concentrations of water soluble $\mathrm{P}$ in the soils and in biochar were measured prior to biochar incorporation to soils in the laboratory. Experiments with three dominant soil textures- silt loam, clay loam and an intermediate loam soil with different rates of biochar addition (i.e., 0.5, 1, 2 and $4 \%$; w/w) showed that the highest concentration of water soluble $\mathrm{P}$ was achieved at an application rate of $1 \%$. At higher application rates, $\mathrm{P}$ concentrations decreased which coincided with a $\mathrm{pH}$ increase of 0.3 - 0.7 units. When the eleven soils were amended with $1 \%(\mathrm{w} / \mathrm{w})$ biochar, water soluble P concentrations increased in most of the soils ranging from 11 to 253\%. However, much of the water soluble P added through the biochar was retained (33 - 100\%). We concluded that - wheat residue char can act as a source of soluble $\mathrm{P}$; and low and high additions of biochar can have different effects on soil solution $\mathrm{P}$ concentration due to possible reactions with $\mathrm{Ca}$ and $\mathrm{Mg}$ added with biochar.
\end{abstract}

Key words: biochar, water soluble phosphorus, phosphorus saturation, phosphorus retention, clay soils, sandy soils. 


\section{Introduction}

Phosphorus (P) is an essential macronutrient for plants and is added to soil in significant amounts when biochar is used as soil amendment. Concentrations of $\mathrm{P}$ (and other nutrients) in biochars are several times higher than in other organic materials because the charring process reduces the biomass volume by $60 \%$ to $90 \%$ (Brown 2009).

Field applications of biochar have been shown to increase soil fertility and productivity by improving soil physical (e.g. Liang et al. 2006; Downie et al. 2009), chemical (e.g. Glaser et al. 2002; Major et al. 2009), and biological properties (e.g. Pietikainen et al. 2000; Rondon et al. 2007). Biochar increases water and nutrient retention capacity in soil (Verheijen et al. 2010) and improves nutrient use efficiency of growing plants (Chan et al. 2007). Thereby, increased crop yields were recorded in fields amended with biochar (Iswaran et al. 1980; Lehman et al. 2003; Yamoto et al. 2006; Chan et al. 2007; Rondon et al. 2007). However, crop yield is often influenced by the availability of $\mathrm{P}$ and the effect of biochar application on $\mathrm{P}$ availability in soil is not well understood.

Instant availability of $\mathrm{P}$ for plant uptake (Van Der Paauw 1971; Beegle 2005) and for leaching and/or runoff losses (Maguire et al. 2005; Ulén et al. 2010; Parvage et al. 2011) depends on the concentration of $\mathrm{P}$ in soil solution. An estimation of water soluble P (WSP) in soil is a direct and simple measure of $\mathrm{P}$ concentration in soil solution (Van Der Paauw 1971; Self-Davis et al. 2000; Beegle 2005; Ulén et al. 2010).

The aim of this study was to investigate changes in WSP concentrations after addition of wheat residue char (biochar) in a range of soils with different textural classes. The hypotheses tested were: (i) biochar increases WSP in soil after application due to high concentrations of WSP in the ash fraction of biochar; (ii) WSP added with biochar is partly adsorbed on soil particles in accordance with the number of soil $\mathrm{P}$ binding sites, i.e., clay content, available $\mathrm{Al}$, Fe and, Ca, and organic $\mathrm{C}$; and (iii) calcium present in biochar increases soil $\mathrm{pH}$ and may precipitate WSP in soil.

\section{Materials and Methods}

\section{Experimental design}

The experiment was divided into two steps. In an initial screening experiment, three soils representing dominant soil textures - Skottorp (silt loam), Flinkesta (clay loam) and Flinkesta (an intermediate loam soil) were amended with biochar at rates of $0.5 \%, 1 \%, 2 \%$ and $4 \%(\mathrm{w} / \mathrm{w})$ to find out the suitable amounts of biochar addition that would yield maximum WSP concentration in biochar amended soil. Mixtures of $6 \mathrm{~g}$ of dry soil and corresponding amounts of biochar (e.g. 0.03 g, $0.06 \mathrm{~g}$, and so on) were transferred into $50 \mathrm{ml}$ plastic centrifuge tubes and $18 \mathrm{ml}$ of distilled water was added. The suspensions were then incubated for 16 hours to facilitate equilibrium concentrations between the solid and liquid phase and, were gently shaken (end over end) during the entire incubation period. Thereafter, the suspensions were centrifuged for 20 minutes at 2817g. The supernatants were then passed through $0.45 \mu \mathrm{m}$ membrane filters (Schleicher and Schüll GmbH, Dassel, Germany) and analysed for WSP colorimetrically (Murphy and Riley 1962). The maximum WSP concentrations were measured at an addition of $1 \%$ biochar. 
In the main experiment all soils were experiment, all soils were therefore amended with $1 \%$ biochar and the same incubation time and analytical procedures were applied as described above. All experiments were replicated three times.

\section{Biochar analysis}

The biochar used was from a Swedish commercial producer named EcoEra AB (Östra Tommarp, Sweden) and originates from a mixture of seed coat, chaff and residues from winter wheat. The chemical composition of the biochar is given in Table 1.

Water soluble $\mathrm{P}$, calcium (Ca), potassium (K), and magnesium (Mg) in the biochar were measured by inductively coupled plasma - atomic emission spectrophotometer (ICP-AES Optima 5300) after shaking biochar with water for 1 hour as proposed by Self-Davis et al. (2000) using a ratio of biochar to water of 5:1. In addition, water soluble chlorine (Cl) and sulfur (S) in the biochar were determined on an ion chromatography system (ICS-90) from the same extract. Total contents of $\mathrm{P}, \mathrm{K}, \mathrm{Ca}, \mathrm{Mg}$ and $\mathrm{Fe}$ (iron) in the biochar were measured with ICP-AES Optima 5300 and $\mathrm{S}$ and $\mathrm{Cl}$ in ICS-90 after digestion with 7 $\mathrm{M} \mathrm{HNO}_{3}$ (SIS 1997). Concentrations of total C and total $\mathrm{N}$ in the biochar were determined using dry combustion of biochar at $1050^{\circ} \mathrm{C}$ for $5 \mathrm{~min}$, whereby the concentrations of $\mathrm{C}$ and $\mathrm{N}$ in the vapor were measured with a LECO CN2000 analyzer (LECO Cooperation 2003). Heavy metal contents (i.e., lead, Pb; cadmium, $\mathrm{Cd}$; and mercury, Hg) in the biochar were provided by the producer.

Soil analyses
Eleven agricultural fields located in eight counties (Table 2) were chosen, representing the dominant soil texture classes of Swedish agricultural lands. Eight subsamples, taken from 0-10 cm depth after autumn harvest from each field, were pooled and thoroughly mixed. Samples were dried at $40^{\circ} \mathrm{C}$, grounded and passed through a $2 \mathrm{~mm}$ sieve. Dried samples of $<2 \mathrm{~mm}$ diameter were used for further experimentations.

Water soluble $\mathrm{P}$ in soils was determined colorimetrically (Murphy and Riley 1962) by using a Shimadzu UV-1201 spectrophotometer after shaking soil with water for 1 hour applying a ratio of soil to water of 3:1. Plant available $\mathrm{P}, \mathrm{Al}$, $\mathrm{Fe}$ and $\mathrm{Ca}$ in soils and biochar were extracted with ammonium acetate lactate (AL extractable) at $\mathrm{pH}$ 3.75 (Egnér et al. 1960) and analysed by ICP-AES Optima 5300. The degree of P saturation (DPS) in soils was calculated as the ratio of the elements on a molar basis in the AL extract using the equation:

DPS $=[$ AL extractable $\mathrm{P} \div(\mathrm{AL}$ extractable $\mathrm{Fe}$ + AL extractable Al)] x 100------------- (i)

Concentrations of organic $\mathrm{C}$ were determined after combustion of soils at $1250^{\circ} \mathrm{C}$ for 5 minutes with LECO CN2000 analyser (LECO Corporation 2003). The $\mathrm{pH}$ was determined in distilled water using a glass electrode; the ratio of soil (and/or biochar) to water was 5:1. Strongly bound P (2M $\mathrm{HCl}-\mathrm{P}$ ) was determined after digestion with $2 \mathrm{M}$ $\mathrm{HCl}$ for 2 hours. Digested suspensions were filtered and the concentrations of $\mathrm{P}$ were measured by ICP-AES (KLS 1965). Soil texture was analysed using the pipette method and classified according to the Food and Agricultural Organization of the United Nations (FAO-ISRIC 1990). 


\section{Statistical analysis}

Treatment effects were statistically analysed by one-way ANOVA and Tukey adjusted multiple mean comparisons using the general linear model procedure of the statistical software MINITAB 16. Correlations between different $\mathrm{P}$ forms and their characteristic elements were determined by using the Pearson correlation method. Linear regression modeling was used to investigate relationships between variables. The confidence level used for the analysis was $95 \%$.

\section{Results and discussion}

\section{Addition of $P$ with biochar}

The biochar material was rich in macronutrients consisting of $0.9 \% \mathrm{P}, 2.9 \% \mathrm{~N}, 2.5 \% \mathrm{Ca}, 1.8 \% \mathrm{~K}$, $0.5 \% \mathrm{Mg}, 0.2 \% \mathrm{~S}$, and had a $\mathrm{pH}$ value of 8.9
(Table 1). In particular, concentrations of water soluble P, K, Cl and S were high (543, 8826, 1428 and $417 \mathrm{mg} \mathrm{kg}^{-1}$ biochar, respectively) corresponding to $6 \% \mathrm{P}, 49 \% \mathrm{~K}, 89 \% \mathrm{Cl}$, and $24 \%$ $\mathrm{S}$ of the total contents. In contrast, $\mathrm{Ca}$ and $\mathrm{Mg}$ in biochar had a low solubility in water amounting to only 0.1 and $1.5 \%$ of the total content, respectively. High solubility of macronutrients in water extract probably resulted from the ash in the charred material. Glaser et al. (2002) described ash as a source of readily available nutrients for plant uptake in soils amended with biochar. Christensen (1977) and Ohno and Erich (1990) observed significant increase of available plant nutrients in soils receiving ash after forest fire. Heavy metal contents in the biochar were low (Table 1), not exceeding the maximum applicable limits when applied to agricultural land within the EU (Pollak and Favoino 2004).

Table 1: Chemical compositions of the biochar used as soil amendment and the amount of different compounds added; values within parentheses express the percentage of the total content

\begin{tabular}{|c|c|c|c|c|}
\hline \multirow{3}{*}{ Characteristics } & \multicolumn{2}{|c|}{ Concentrations } & \multicolumn{2}{|c|}{ Amount added with $1 \%(\mathrm{w} / \mathrm{w})$ biochar* } \\
\hline & Total & Water soluble & Total & Water soluble \\
\hline & \multicolumn{2}{|c|}{$\mathrm{g} \mathrm{kg}^{-1}$} & \multicolumn{2}{|c|}{$\mathrm{kg} \mathrm{ha}^{-1}$} \\
\hline Moisture & 140 & - & $1680-2100$ & - \\
\hline Ash & 205 & - & $2460-3075$ & - \\
\hline Carbon (C) & 637 & - & $7644-9555$ & - \\
\hline Nitrogen (N) & 29 & - & $348-435$ & - \\
\hline Sulfur (S) & 1.7 & $0.4(25)$ & $20.4-25.5$ & $4.8-6.0$ \\
\hline Chlorine (Cl) & 1.6 & $1.4(89)$ & $19.2-24$ & $16.8-21$ \\
\hline Calcium (Ca) & 24.9 & $0.03(0.1)$ & $299-373$ & $0.36-0.45$ \\
\hline Potassium (K) & 18.1 & $8.8(49)$ & $217-271$ & $106-132$ \\
\hline Phosphorus (P) & 9.1 & $0.5(6.0)$ & $109-136$ & $6.0-9.0$ \\
\hline Magnesium (Mg) & 5.1 & 0.08 (1.5) & $61.2-76.5$ & $0.95-1.18$ \\
\hline Iron (Fe) & 1.9 & - & $22.8-28.5$ & - \\
\hline Lead (Pb) & $<0.01$ & - & $<0.1$ & - \\
\hline Cadmium (Cd) & $<0.001$ & - & $<0.01$ & - \\
\hline Mercury (Hg) & $<0.0001$ & - & $<0.001$ & - \\
\hline
\end{tabular}


We have calculated that an application rate of $1 \%(\mathrm{w} / \mathrm{w})$ biochar to the top $10 \mathrm{~cm}$ of soil on a hectare basis is equivalent to an amount of approximately $12 \mathrm{t}$ in clay and $15 \mathrm{t}$ in a sandy soil assuming a bulk density of 1.2 and $1.5 \mathrm{~g} \mathrm{~cm}^{-3}$, respectively. Addition of $12-15 \mathrm{t}$ of biochar in the soil means an input of $109-136 \mathrm{~kg} \mathrm{P}$ and 348 - $435 \mathrm{~kg} \mathrm{~N}$ to soil (see Table 1), which is in agreement with other studies (Kishimoto and Sugiura 1985; Atkinson et al. 2010). The amount of WSP added with biochar was $6.0-9.0 \mathrm{~kg} \mathrm{ha}^{-1}$.

Phosphorus in soils before and after biochar addition

Background concentrations of WSP in soils ranged from 0.06 to $6.03 \mathrm{mg} \mathrm{P} \mathrm{kg}^{-1}$ soil, and $\mathrm{AL}$ extractable $\mathrm{P}$ concentrations ranged from 33 to 139 mg $\mathrm{P} \mathrm{kg}^{-1}$ soil (see Table 2). Soil organic C contents varied between $2.2 \%$ and $11.6 \%$. Concentrations of strongly bound $\mathrm{P}(2 \mathrm{M} \mathrm{HCl}-\mathrm{P}$ ) ranged from 302 to $1017 \mathrm{mg} \mathrm{P} \mathrm{kg}^{-1}$ soil and were positively correlated with clay content $\left(R^{2}\right.$ adjust- ed $=0.62, p=0.002 ; n=11)$. In the initial screening experiment, biochar addition increased WSP concentration in three soils due to direct addition of WSP from the biochar. However, addition of increasing amounts of biochar (i.e. control, 0.5, 1, 2 and 4\%) did not result in a corresponding increase of WSP. The highest WSP concentrations were observed at a rate of $1 \%$ biochar addition, thereafter, a significant ( $\mathrm{p}<$ 0.01) decrease was observed when the rates of biochar application were increased from $1 \%$ to $4 \%$ in conjunction with a $\mathrm{pH}$ increase of $0.3-0.7$ units.

Applying 1\% biochar resulted only a slight shift in soil $\mathrm{pH}$ (0.1 - 0.2 units). The effect of different amount of biochar addition on soil WSP concentration and $\mathrm{pH}$ differed between soils, probably due to variations of the soil properties mentioned in Table 2. Similar to our findings, Wang et al. (2011) and Yao et al. (2011) also reported small increase of soil $\mathrm{pH}$ after biochar addition varying among soils.

Table 2: Properties of the soils: water soluble phosphorus (WSP); phosphorus, aluminium, iron and calcium in ammonium acetate lactate extract (extractable $\mathrm{P}, \mathrm{Al}, \mathrm{Fe}$ and $\mathrm{Ca}$ ); degree of $\mathrm{P}$ saturation (DPS); strongly bound P (2M HCl - P); and organic carbon (C)

\begin{tabular}{|c|c|c|c|c|c|c|c|c|c|c|}
\hline $\begin{array}{l}\text { Name of the soil } \\
\text { and texture }\end{array}$ & Clay & WSP & $\begin{array}{c}\text { Extractab } \\
\mathrm{P}\end{array}$ & $\begin{array}{l}\text { e } 2 \mathrm{M} \mathrm{HCl} \\
-\mathrm{P}\end{array}$ & \multirow{2}{*}{$\begin{array}{c}\text { DPS } \\
\%\end{array}$} & $\begin{array}{c}\text { Extractable } \\
\mathrm{Al}\end{array}$ & $\begin{array}{l}\text { Extractable } \\
\text { Fe }\end{array}$ & $\begin{array}{c}\text { Extractable } \\
\mathrm{Ca}\end{array}$ & \multirow[t]{2}{*}{$\mathrm{pH}$} & \multirow{2}{*}{$\begin{array}{l}\mathrm{C} \\
\%\end{array}$} \\
\hline & $\%$ & & & $\mathrm{mg} \mathrm{kg}^{-1}$ & & & $\mathrm{mg} \mathrm{kg}^{-1}$ & & & \\
\hline Skottorp Silt loam & 8 & 2.76 & 72 & 303 & 13 & 422 & 155 & 1590 & 6.4 & 3.1 \\
\hline Hassla Silt loam & 8 & 1.11 & 88 & 332 & 12 & 564 & 209 & 1026 & 6 & 5.5 \\
\hline Röbäcksdalen Loam & 10 & 0.66 & 114 & 490 & 12 & 440 & 740 & 1720 & 6.2 & 5.2 \\
\hline Näsbygård Loamy sand & 11 & 4.74 & 83 & 302 & 26 & 178 & 200 & 1794 & 6.6 & 2.2 \\
\hline Flinkesta Loam & 22 & 3.96 & 33 & 359 & 7 & 266 & 278 & 1094 & 5.4 & 3.3 \\
\hline Östergötland Clay loam & 32 & 0.15 & 67 & 606 & 19 & 190 & 247 & 31596 & 7.7 & 2.9 \\
\hline $\begin{array}{l}\text { Östergötland Silty clay } \\
\text { loam }\end{array}$ & 35 & 1.2 & 139 & 811 & 14 & 533 & 721 & 4604 & 6.2 & 8.0 \\
\hline Flinkesta Clay loam & 38 & 6.03 & 34 & 531 & 7 & 220 & 364 & 1584 & 5.9 & 3.8 \\
\hline Uppsala Clay loam & 39 & 0.06 & 51 & 694 & 4 & 665 & 986 & 5013 & 5.9 & 11.6 \\
\hline Uppsala Silty clay & 55 & 0.63 & 81 & 1017 & 3 & 1366 & 1446 & 6809 & 5.3 & 3.4 \\
\hline Södermanland Clay & 66 & 0.12 & 71 & 692 & 4 & 940 & 1233 & 1786 & 5.3 & 8.0 \\
\hline
\end{tabular}


In the main experiment, applying 1\% biochar to all soils, an increase of WSP ranging from $11 \%$ to $253 \%$ (Table 3) was found. However, in some soils, a relative decrease of $5 \%$ or no changes was also measured as compared to the untreated soils. In fact, when the expected increase of WSP in soils upon biochar addition was calculated, we found that a major portion of WSP (33 - 100\%) of the biochar was retained (Table 3) upon mixing with soil.

Table 3: Changes of water soluble P (WSP) in soils after addition of $1 \%$ biochar to each soil; values within parentheses express the percentage increased after biochar addition

\begin{tabular}{|c|c|c|c|}
\hline \multirow[t]{2}{*}{$\begin{array}{l}\text { Name of the soil } \\
\text { and texture }\end{array}$} & $\begin{array}{c}\text { WSP, } \\
\text { soil } \\
\text { only }\end{array}$ & $\begin{array}{c}\text { WSP } \\
\text { measured, } \\
\text { soil + } 1 \% \\
\text { biochar* }\end{array}$ & \multirow[t]{2}{*}{$\begin{array}{l}\text { Portion of } \\
\text { WSP from } \\
\text { biochar } \\
\text { retained in } \\
\text { soil } \\
\%\end{array}$} \\
\hline & \multicolumn{2}{|c|}{$\mathrm{mg} \mathrm{kg}^{-1}$} & \\
\hline Skottorp Silt loam & 2.76 & $4.43(61)$ & 69 \\
\hline Hassla Silt loam & 1.11 & $1.55(40)$ & 92 \\
\hline Röbäcksdalen Loam & 0.66 & $0.95(44)$ & 95 \\
\hline $\begin{array}{l}\text { Näsbygård Loamy } \\
\text { sand }\end{array}$ & 4.74 & $5.25(11)$ & 91 \\
\hline Flinkesta Loam & 3.96 & $7.61(92)$ & 33 \\
\hline $\begin{array}{l}\text { Östergötland Clay } \\
\text { loam }\end{array}$ & 0.15 & $0.53(253)$ & 93 \\
\hline $\begin{array}{l}\text { Östergötland Silty } \\
\text { clay loam }\end{array}$ & 1.2 & $1.14(-5)$ & 101 \\
\hline Flinkesta Clay loam & 6.03 & $7.23(20)$ & 78 \\
\hline Uppsala Clay loam & 0.06 & $0.09(50)$ & 100 \\
\hline Uppsala Silty clay & 0.63 & $1.17(86)$ & 90 \\
\hline Södermanland Clay & 0.12 & $0.12(0)$ & 100 \\
\hline
\end{tabular}

\section{Phosphorus retention in biochar-amended soils}

To find out whether there was any relationship between retention of WSP and soil parameters, $\mathrm{AL}$ extractable $\mathrm{Al}, \mathrm{Fe}$, and $\mathrm{Ca}$, clay content, organic C, DPS and $\mathrm{pH}$ were correlated with retained portion of WSP. Pierzynski et al. (2005),
Brady and Weil (2002), Hinsinger (2001) and others described retention of WSP in soils through adsorption to clay minerals, organic matter, and $\mathrm{Al}^{3+}, \mathrm{Fe}^{2+/ 3+}$ and $\mathrm{Ca}^{2+}$ sites. Parvage et al. (2011) found a large potential for $\mathrm{P}$ retention in soils having low degrees of $\mathrm{P}$ saturation (DPS) after after adding soluble $\mathrm{P}$ to the soils. Nonetheless, no significant correlations were observed between the retained amount of WSP added through biochar and the soil properties tested. Only a weak correlation was found using all soil parameters as predictor variables against the WSP in a linear regression model $\left(\mathrm{R}^{2}\right.$ adjusted $=0.42, p=0.232$; $\mathrm{n}=11$ ) indicating that adsorption of $\mathrm{P}$ to soil binding sites might not be the main mechanism for WSP retention in soil amended with biochar.

Another possible retention mechanism for $\mathrm{P}$ in biochar amended soil is through binding to positively charged metal complexes formed on biochar surfaces (Beaton et al. 1959; DeLuca et al. 2009). A third possible mechanism could be precipitation of WSP with $\mathrm{Ca}^{2+}$ (Hedley and McLaughlin 2005; Ulén and Snäll 2007) and, $\mathrm{Mg}^{2+}$ (Sales et al. 1992; Rahaman et al. 2008) present in the solution coming from the dissolution of ash (Erich 1991; Etiégni and Campbell 1991) in the biochar. However, the actual concentrations of soluble $\mathrm{Ca}$ and $\mathrm{Mg}$ in the water extract of biochar (Table 1) were far below the precipitation limit for any kind of Ca-P (or Mg-P) compounds (Lindsay 1979).

A further reaction that could affect WSP concentration in biochar-amended soil is that $\mathrm{Ca}$, $\mathrm{Mg}$ and $\mathrm{K}$ ions added with biochar may cause flocculation of colloidal soil P. As a consequence, larger soil colloids formed may not pass through the $0.45 \mu \mathrm{m}$ filter whereby lower WSP concentrations are measured (Koopmans et al. 2005). The decrease in WSP in soil at increas- 
ing rates of biochar addition may also be explained by the flocculation mechanisms as the flocculation conditions for colloidal $\mathrm{P}$ were favored by adding more of those cations through more biochar, which also resulted in an increase of bulk soil pH by 0.3-0.7 units.

\section{Conclusions}

This study showed that (i) wheat residue char can act as a source of soluble $\mathrm{P}$ although a major fraction of WSP in biochar was retained in soil; (ii) two mechanisms seem to be responsible for $\mathrm{P}$ retention - adsorption on soil $\mathrm{P}$ binding sites and flocculation of $\mathrm{P}$ through cations added with biochar and; (iii) biochar acted as a sink instead of a source of $\mathrm{P}$ when applied at high quantity (2 $4 \%$ of soil weight for $0-10 \mathrm{~cm}$ ).

\section{Acknowledgement}

The project was partly financed by The Royal Swedish Academy of Agriculture and Forest research grant.

\section{References}

Atkinson CJ, Fitzgerald JD, Hipps NA (2010) Potential mechanisms for achieving agricultural benefits from biochar application to temperate soils: a review. Plant Soil 337: 118

Beaton JD, Peterson HB, Bauer N (1959) Some aspects of phosphate adsorption by charcoal. Soil Sci Soc Am J 24: 340-346

Beegle D (2005) Assessing soil phosphorus for crop production by soil testing. In: Sims JT, Sharpley AN (Eds) Phosphorus: Agriculture and the Environment. Agron Monog No. 46. Madison, Wisconsin, pp 123-143
Brady NC, Weil RR (2002) The Nature and Properties of Soils, $13^{\text {th }}$ edition. Pearson Education Ltd, New Jersey

Brown R (2009) Biochar production technology. In: Lehmann J, Joseph S (Eds) Biochar for Environmental Management: Science and Technology. Earthscan, London, pp 127-146

Chan KY, Van Zwieten L, Meszaros I, Downie A, Joseph S (2007) Agronomic values of greenwaste biochar as a soil amendment. Aust J Soil Res 45: 629-634

Christensen NL (1977) Fire and soil-plant nutrient relations in a pine-wiregrass savanna on the coastal plain of North Carolina. Oecologia 31: 27-44

DeLuca HT, MacKenzie MD, Gundale MJ (2009) Biochar effects on soil nutrient transformations. In: Lehmann J, Joseph S (Eds) Biochar for Environmental Management: Science and Technology. Earthscan, London, pp 251-270

Downie A, Crosky A, Munroe P (2009) Physical properties of biochar. In: Lehmann J, Joseph S (Eds) Biochar for Environmental Management: Science and Technology. Earthscan, London, pp 13-32

Egnér H, Riehm H, Domingo WR (1960) Untersuchungen über die chemische Bodenanalyse als Grundlage für die Beurteiling des Nährstoffzustandes der Böden. II Chemische Extrationsmethoden zur Phosphor- och Kaliumbestimmung. Kung Lantbruk Annal 26: 199-215 (In German)

Erich MS (1991) Agronomic Effectiveness of Wood Ash as a Source of Phosphorus and Potassium. J Environ Qual 20: 576-581

Etiégni L, Campbell AG (1991) Physical and Chemical Characteristics of Wood Ash. Bioresource Technol 37: 173-178 
FAO-ISRIC (1990) Guidelines for soil description, FAO, Rome

Glaser B, Lehmann J, Zech W (2002) Ameliorating physical and chemical properties of highly weathered soils in the tropics with charcoal - a review. Biol Fertil Soils 35: 219230

Hedley M, McLaughlin M (2005) Reactions of Phosphate Fertilizers and By-Products in Soil. In: Sims JT, Sharpley AN (Eds) Phosphorus: Agriculture and the Environment. Agron Monog No. 46. Madison, WI, pp 181-252

Hinsinger P (2001) Bioavailability of soil inorganic $\mathrm{P}$ in the rhizosphere as affected by root-induced chemical changes: a review. Plant Soil 237: 173-195

Iswaran V, Jauhri KS, Sen A (1980) Effect of charcoal, coal and peat on the yield of moong, soybean and pea. Soil Biol Biochem 12: 191192

Kishimoto S, Sugiura G (1985) Charcoal as a soil conditioner. Intern Achiev Future 5: 12-23

KLS (1965) Kungliga Lantbruksstyrelsens kungörelse med (5) bestämmelser för undersökning av jord vid statens lantbrukskemiska kontrollanstalt och lantbrukskemisk kontrollstation och lantbrukskemisk station med av staten fastställda stadgar. Kungl Lantbruk kungör, $\mathrm{Nr}$ 1 (In Swedish).

Koopmans GF, Chardon WJ, Van der Salm C (2005) Disturbance of water-extractable phosphorus determination by colloidal particles in a heavy clay soil from the Netherlands. J Environ Qual 34: 1446-1450

LECO Corporation (2003) Organic Application Note, LECO CN2000 (brochure), St. Joseph, Michigan

Lehmann J, Kern D, German L, McCann J, Martins GC, Moreira L (2003) Soil fertility and production potential. In: Lehmann J, Kern DC, Glaser B, Woods WI (Eds) Amazonian dark earths: Origin, properties, management. Kluwer Academic, Dordrecht, pp 105-124

Liang B, Lehmann J, Solomon D, Kinyangi J, Grossman J, O’Neill B, Skjemstad JO, Thies J, Luizao FJ, Peterson J, Neves EG (2006) Black carbon increases cation exchange capacity in soils. Soil Sci Soc Am J 70: 1719-1730

Lindsay WL (1979) Chemical equilibria in soils. John Wiley \& Sons, New York

Maguire RO, Chardon WJ, Simard RR (2005) Assessing potential environmental impact of soil phosphorus by soil testing. In: Sims JT, Sharpley AN (Eds) Phosphorus: Agriculture and the Environment. Agron Monog No. 46. Madison, Wisconsin, pp 145-180

Major J, Steiner C, Downie A, Lehmann J (2009) Biochar effects on nutrient leaching. In: Lehmann J, Joseph S (Eds) Biochar for Environmental Management: Science and Technology. Earthscan, London, pp 271-287 Murphy J, Riley JP (1962) A modified single solution method for the determination of phosphate in natural waters. Analyt Chim Acta 27: 31-36

Ohno T, Erich MS (1990) Effect of wood ash application on soil $\mathrm{pH}$ and soil test nutrient levels. Agri Eco Environ 32: 223-239

Parvage MM, Kirchmann H, Kynkäänniemi P, Ulén B (2011) Impact of horse grazing and feeding on phosphorus concentrations in soil and drainage water. Soil Use Manage 27: 367375

Pierzynski GM, McDowell RW, Sims JT (2005) Chemistry, cycling, and potential movement of inorganic phosphorus in soils. In: Sims JT, Sharpley AN (Eds) Phosphorus: Agriculture and the Environment. Agron Monog No. 46. Madison, WI, pp 53-86 
Pietikäinen J, Kiikkilä O, Fritze H (2000) Charcoal as a habitat for microbes and its effect on the microbial community of the underlying humus. Oikos 89: 231-242

Pollak M, Favoino E (2004) Heavy Metals and Organic Compounds from Wastes Used as Organic

Fertilisers. http://ec.europa.eu/environment/wa ste/compost/pdf/hm_annex2 Accessed 17 May 2011

Rahaman MS, Ellis N, Mavinic DS (2008) Effects of various process parameters on struvite precipitation kinetics and subsequent determination of rate constants. Water Sci Technol 57: 647-654

Rondon MA, Lehmann J, Ramirez J, Hurtado M (2007) Biological nitrogen fixation by common beans (Phaseolus vulgaris $L$ ) increases with bio-char additions. Biol Fertil Soils 43: 699-708

Sales BC, Chakoumakos BC, Boatner LA, Ramey JO (1992) Structural evolution of the amorphous solids produced by heating crystalline $\mathrm{MgHPO}_{4} \cdot 3 \mathrm{H}_{2} \mathrm{O}$. J Mater Res 7: 2646-2649

Self-Davis ML, Moore PA, Joern BC (2000) Determination of water-and/or dilute saltextractable phosphorus. In: Pierzynski GM (Ed) Methods for phosphorus analysis for soils, sediments, residuals, and waters. South Coop Ser Bul 396: 24-26

SIS (1997) Soil analysis determination of trace elements in soils extraction with nitric acids: Swedish Standard SS-28311. Swedish Standard Institute (SIS), Stockholm, Sweden
Ulén B, Snäll S (2007) Forms and retention of phosphorus in an illite-clay soil profile with a history of fertilisation with pig manure and mineral fertilisers. Geoderma 137: 455-465

Ulén B, Djodjic F, Etana A, Johansson G, Lindström J (2010) The need for improved risk index for phosphorus losses to water from tiledrained agricultural land. J Hydrol 400: 234243

Van Der Paauw F (1971). An effective water extraction method for the determination of plant-available soil phosphorus. Plant Soil 34: 467-481

Verheijen F, Jeffery S, Bastos AC, Van der Velde M, Diafas I (2010) Biochar Application to Soils-A Critical Scientific Review of Effects on Soil Properties, Processes and Functions. EUR - Scientific and Technical Research series. ISSN 1018-5593. ISBN 978-92-7914293

Wang J, Zhang M, Xiong Z, Liu P, Pan G (2011) Effects of biochar addition on $\mathrm{N}_{2} \mathrm{O}$ and $\mathrm{CO}_{2}$ emmissions from two paddy soils. Biol Fertil Soils 47: 887-896

Yamato M, Okimori Y, Wibowo IF, Anshori S, Ogawa M (2006) Effects of the application of charred bark in Acacia mangium on the yield of maize, cowpea, peanut and soil chemical properties in south Sumatra, Indonesia. Soil Sci Plant Nutr 52: 489-495

Yao H, Campbell CD, Qiao X (2011) Soil pH controls nitrification and carbon substrate utilization more than urea or charcoal in some highly acidic soils. Biol Fertil Soils 47: 515522 